admissions, despite optimal pharmacologic and non-pharmacologic treatment, and always with an accurate clinical and bacteriological control in reference centers. ${ }^{14}$ This recommendation concurs with that expressed by other experts in recent reviews on this type of therapy. ${ }^{12,15}$

Treatment with long-term antibiotics is a clear example of a necessary collaboration between primary and secondary care. Primary care physicians must be alert to the possibility and identify those patients who could potentially benefit from this therapy, and secondary care must assess the patients' suitability, optimising baseline treatment, investigating the presence of bronchiectasis and possible chronic bronchial infection - including the patterns of resistance to antibiotics to the identified microorganisms - and evaluating heart and liver function before long-term treatment with macrolides can be indicated.

However, some questions must be addressed before a broader recommendation on the use of long-term antibiotics in COPD can be made. It is not clear which is the best antibiotic, whether it is better to use the same drug or rotate different antibiotics, which is the best dose for macrolides and, once started, what the duration of treatment should be. For all these reasons the use of long-term antibiotics in COPD must be restricted to a very selective subgroup (or phenotype) of patients with close supervision by primary and secondary care.

Conflicts of interest Marc Miravitlles has received speaker fees from Boehringer Ingelheim, Pfizer, AstraZeneca, Bayer Schering, Novartis, Talecris-Grifols, Takeda-Nycomed, Merck, Sharp \& Dohme and Novartis, and consulting fees from Boehringer Ingelheim, Pfizer, GSK, AstraZeneca, Bayer Schering, Novartis, Almirall, Merck, Sharp \& Dohme, Talecris-Grifols and Takeda-Nycomed.

Commissioned article; not externally peer-reviewed; accepted 5th July 2013; online 21st August 2013

(C) 2013 Primary Care Respiratory Society UK. All rights reserved

http://dx.doi.org/10.4104/pcrj.2013.00074

Prim Care Respir J 2013; 22(3): 261-262

\section{References}

1. Vestbo J, Hurd SS, Agusti AG, Jones PW, Vogelmeier C, Anzueto A. Global Strategy for the Diagnosis, Management and Prevention of Chronic Obstructive Pulmonary Disease, GOLD Executive Summary. Am J Respir Crit Care Med 2013;187:347-65. http://dx.doi.org/10.1164/rccm.201204-0596PP

2. Staykova T, Black PN, Chacko EE, Poole P. Prophylactic antibiotic therapy for chronic bronchitis. Cochrane Review. Published online: 21 Jan 2009. http://dx.doi.org/10.1002/14651858.CD004105

3. Garcha DS, Thurston SJ, Patel ARC, et al. Changes in prevalence and load of airway bacteria using quantitative PCR in stable and exacerbated COPD. Thorax 2012;67: 1075-80. http://dx.doi.org/10.1136/thoraxjnl-2012-201924

4. Singh S, Amin AV, Loke YK. Long-term use of inhaled corticosteroids and the risk of pneumonia in chronic obstructive pulmonary disease. JAMA 2009;169:219-29.

5. Bafadhel M, McKenna S, Terry S, et al. Blood eosinophils to direct corticosteroid treatment of exacerbations of chronic obstructive pulmonary disease a randomized placebo-controlled trial. Am J Respir Crit Care Med 2012;186:48-55. http://dx.doi.org/10.1164/rccm.201108-15530C

6. Miravitlles M, Soler-Cataluña JJ, Calle M, Soriano J. Treatment of COPD by clinical phenotypes. Putting old evidence into clinical practice. Eur Respir J 2013;41:12526. http://dx.doi.org/10.1183/09031936.00118912

7. Matkovic Z, Miravitlles M. Chronic bronchial infection in COPD. Is there an infective phenotype? Respir Med 2013;107:10-22

http://dx.doi.org/10.1016/j.rmed.2012.10.024

8. James GD, Petersen I, Nazareth I, Wedzicha JA, Donaldson GC. Use of long-term antibiotic treatment in COPD patients in the UK: a retrospective cohort study. Prim Care Respir J 2013;22(3):271-7. http://dx.doi.org/10.4104/pcrj.2013.00061

9. Sethi S, Jones PW, Theron MS, et al. for the PULSE Study group. Pulsed moxifloxacin for the prevention of exacerbations of chronic obstructive pulmonary disease: a randomized controlled trial. Respir Res 2010;11:10.

http://dx.doi.org/10.1186/1465-9921-11-10

10. Seemungal TA, Wilkinson TM, Hurst JR, Perera WR, Sapsford RJ, Wedzicha JA. Long-term erythromycin therapy is associated with decreased chronic obstructive pulmonary disease exacerbations. Am J Respir Crit Care Med 2008;178:1139-47. http://dx.doi.org/10.1164/rccm.200801-1450C

11. Albert RK, Connett J, Bailey WC, et al. Azithromycin for prevention of exacerbations of COPD. N Engl J Med 2011;365:689-98. http://dx.doi.org/10.1056/NEJMoa1104623

12. Ray WA, Murray KT, Hall K, Arbogast PG, Stein CM. Azithromycin and the risk of cardiovascular detah. N Engl J Med 2012;366:1881-90. http://dx.doi.org/10.1056/NEJMoa1003833

13. Serisier DJ. Risks of population antimicrobial resistance associated with chronic macrolide use for inflammatory airway diseases. Lancet Respir Med 2013;1:262-74. http://dx.doi.org/10.1016/\$2213-2600(13)70038-9

14. Miravitlles M, Soler-Cataluña JJ, Calle M, et al. Spanish COPD guidelines (GesEPOC). Pharmacological treatment of stable COPD. Arch Bronconeumol 2012; 48:247-57. http://dx.doi.org/10.1016/j.arbres.2012.04.001

15. Spagnolo P, Fabbri LM, Bush A. Long-term macrolide treatment for chronic respiratory disease. Eur Respir J 2013;42:239-51.

http://dx.doi.org/10.1183/09031936.00136712

\title{
Asthma prevalence and humoral immune response in Somali immigrants in the US: implications for the hygiene hypothesis
}

\section{*Christopher C Butler', Nicholas A Francis' \\ 1 Institute of Primary Care and Public Health, Cardiff University, Cardiff, UK}

*Correspondence: Professor Chris Butler, Professor of Primary Care Medicine, Director of Institute of Primary Care and Public Health, Cardiff University, School of Medicine, 5th Floor, Neuadd Meirionnydd, Heath Park, Cardiff CF14 4XN, UK

Tel: +44 (0)29 20687168 Fax: +44 (0)29 20687219

E-mail: butlercc@cardiff.ac.uk
See linked article by Patel et al. on pg 278

As the social determinants of health improved, ${ }^{1,2}$ so exposure to microbiological diversity reduced ${ }^{3}$ and asthma prevalence increased. ${ }^{4,5}$ The Hygiene Hypothesis suggests a causal relationship between these trends, through an effect of exposure of environmental factors (including invasive and non-invasive infections) on T-helper cells. ${ }^{4,6}$ Children with greater exposure to infections and a wider array of microbes early on in life, according to the hypothesis, can expect to have lower rates of asthma and better 
balanced immune function. ${ }^{7}$

In this issue of the PCRJ, Patel and colleagues studied 89 Somali immigrants living in Olmsted County in Minnesota in the United States. ${ }^{8}$ Firstly, they found that $10(16 \%$ of the 62 children included in the analysis) had asthma, and 22 (35\%) had other atopic conditions, similar prevalences to the general population of children in Rochester, Minnesota. ${ }^{9}$ Secondly, they found lower levels of mumps virus specific antibody levels in those Somali immigrants with asthma compared to those without asthma. The authors therefore conclude that their results may not support the hygiene hypothesis.

The hygiene hypothesis is appealing on many levels, not least to those who are keen to reduce antibiotic prescribing for self-limiting conditions. Evidence supporting the hypothesis may justify comments in primary care consultations to parents of young children with probable viral illnesses such as, "Fighting this illness without antibiotics will make your child's immune system stronger." 10-12 Society in general needs to shift its mindset from a superficial concept of bacteria as being bad and needing to be destroyed ("our cleaner kills $99.9 \%$ of all household germs") to an ecological view of the world where we find better ways of living symbiotically with the micro-organisms we depend on for our well-being and immune competence. Indeed, our microbiome's relationship with immune status is a major developing research area, ${ }^{13}$ and some have come to think of our commensal bacteria as one of our major organs, essential for health and for life itself.

So what can be said about the applicability of Patel and colleague's findings? Study design issues limit our ability to interpret their findings both on asthma prevalence and on humoral immune response to MMR vaccine viruses. The authors describe their study design as "a retrospective cohort study with a cross sectional study component." Their "convenience" sample, a secondary study base of 89 children, was obtained through their participation in a previous study of MMR vaccine response. ${ }^{14}$ Assessing the population prevalence of asthma in Somali immigrants would ideally have relied on systematic ascertainment from actual source population. What proportion of eligible Somali immigrants participated in the original vaccine study? And were there any important differences between those that participated in the original study and those that did not, as well as between the 62 that participated in the present study and the 27 that were excluded from the analyses? No specific hypothesis is tested in the comparison of asthma prevalence in the 62 participants of this study with a much larger, school-based, longitudinal study of physician-diagnosed asthma prevalence in Rochester, Minnesota, that is mentioned in the discussion. ${ }^{9}$ Therefore, we do not know how confident we can be that there is no difference in asthma prevalence between the two samples. The authors do consider the possibility of a Type II error because of the small numbers in their study. However, socio-economic status and other possible confounders were not taken into account when comparing asthma prevalence.

The authors have previously found that Caucasian children with asthma have suboptimal immune responses to the MMR vaccine, ${ }^{15}$ but whether this holds for children who have had increased exposure to a wide array of microbes early on in life is unclear. What can be said for the finding in this study that mumps specific lgG levels were lower in those Somali immigrants with asthma but no difference was found for measles and rubella lgG levels? The authors did adjust for the duration between the MMR vaccination and the date the blood sample was taken, but do not seem to have controlled for other factors such as age.

It would be interesting to know how other factors - such as time in the US, and intensity and duration of exposure to the "Somali environment" pre-natally and after birth - influenced risk of asthma and immune response to vaccinations. Are the early experiences of Somali immigrants in relation to microbiological and other relevant environmental exposures typical of other Somali children, or could it be that there is something about those that end up emigrating that also makes them more similar in this regard to children in urban Minnesota?

The authors are undoubtedly correct in concluding that a straightforward interpretation of the hygiene hypothesis should be made with caution. Potential confounders, as the authors point out, including genetic and epigenetic influences, are likely to apply. ${ }^{6}$ While the concept of this 'natural experiment' study is intriguing, study design issues make it hard to know what the real implications are for the longevity of the hygiene hypothesis...

Conflicts of interest The authors declare that they have no conflicts of interest in relation to this article.

Commissioned article; not externally peer-reviewed; 14th August 2013; online 19th August 2013

(c) 2013 Primary Care Respiratory Society UK. All rights reserved http://dx.doi.org/10.4104/pcrj.2013.00081

Prim Care Respir J 2013; 22(3): 262-264

\section{References}

1. Cosby JL, Francis N, Butler CC. The role of evidence in the decline of antibiotic use for common respiratory infections in primary care. The Lancet infectious diseases 2007;7(11):749-56. Epub 2007/10/27.

2. Kondrashova A, Seiskari T, Ilonen J, Knip M, Hyoty H. The 'Hygiene hypothesis' and the sharp gradient in the incidence of autoimmune and allergic diseases between Russian Karelia and Finland. APMIS. Acta pathologica, microbiologica, et immunologica Scandinavica 2013;121(6):478-93. Epub 2012/11/07.

3. Seiskari T, Kondrashova A, Viskari $\mathrm{H}$, et al. Allergic sensitization and microbial load-a comparison between Finland and Russian Karelia. Clinical and experimental immunology 2007;148(1):47-52. Epub 2007/02/17.

4. Kamradt T, Goggel R, Erb KJ. Induction, exacerbation and inhibition of allergic and autoimmune diseases by infection. Trends in immunology 2005;26(5):260-7. Epub 2005/05/04.

5. Akinbami LJ, Moorman JE, Garbe PL, Sondik EJ. Status of childhood asthma in the United States, 1980-2007. Pediatrics 2009;123 Suppl 3:S131-45. Epub 2009/04/16

6. von Mutius E. Allergies, infections and the hygiene hypothesis--the epidemiological evidence. Immunobiology 2007;212(6):433-9. Epub 2007/06/05.

7. Strachan DP. Hay fever, hygiene, and household size. BMJ 1989;299(6710):125960. Epub 1989/11/18

8. Patel AR, Zietlow J, Jacobson RM, Poland GA, Juhn YJ. Asthma and the immune response to MMR vaccine viruses in Somali immigrant children: a cross-sectional retrospective cohort study. Prim Care Respir J 2013;22(3):278-83. http://dx.doi.org/10.4104/pcrj.2013.00039

9. Yawn BP, Wollan P, Kurland M, Scanlon P. A longitudinal study of the prevalence of asthma in a community population of school-age children. The Journal of Pediatrics 2002;140(5):576-81. Epub 2002/05/29. 
10. Butler CC, Prout H, Kinnersley P, Rollnick S, Edwards A, Elwyn G. Shared decision making and antibiotics in primary care. Journal of Antimicrobial Chemotherapy 2001;48:435-40. http://dx.doi.org/10.1093/jac/48.3.435

11. Cals JW, Scheppers NA, Hopstaken RM, et al. Evidence based management of acute bronchitis; sustained competence of enhanced communication skills acquisition in general practice. Patient education and counseling 2007;68(3):2708. Epub 2007/08/24.

12. Butler CC, Simpson SA, Dunstan F, et al. Effectiveness of multifaceted educational programme to reduce antibiotic dispensing in primary care: practice based randomised controlled trial. BMJ 2012;344:d8173. Epub 2012/02/04.

13. Bendiks M, Kopp MV. The Relationship Between Advances in Understanding the
Microbiome and the Maturing Hygiene Hypothesis. Current allergy and asthma reports 2013. Epub 2013/08/13.

14. St S, Jacobson RM, Vierkant RA, Jacobsen SJ, Green EM, Poland GA. Association of parental vaccination reports with measles, mumps, and rubella protective antibody levels: comparison of Somali immigrant, Hispanic migrant, and US children in Rochester, Minn. Mayo Clinic proceedings 2002;77(3):241-5. Epub 2002/03/13.

15. Yoo KH, Agrawal K, Butterfield M, Jacobson RM, Poland GA, Juhn YJ. Assessment of humoral and cell-mediated immune response to measels-mumps-rubells vaccine viruses among patients with asthma. Allergy Asthma Proc 2010;31(6):499-506. http://dx.doi.org/10.2500/aap.2010.31.3399

\section{Deprivation, winter season, and COPD exacerbations}

\section{Gavin C Donaldson', *Jadwiga A Wedzicha1}

1 Centre for Respiratory Medicine, Royal Free Campus, University College London, London, UK

*Correspondence: Professor Wisia Wedzicha, Professor of Respiratory Medicine, Centre for Respiratory Medicine, Royal Free Campus, University College London, Rowland Hill Street, Hampstead, London, NW3 2PF, UK

Tel: +44 (0)207317 7517 Fax: +44 (0)207 4726141

E-mail:w.wedzicha@ucl.ac.uk

See linked article by McAllister et al. on pg 296

COPD exacerbations are a major cause of hospital admissions, especially during the winter months. They are mainly attributed to the increase in respiratory viral infections, though clearly other factors must also play a part. Some patients with COPD have particular susceptibility to frequent exacerbations, and this patient group is especially at risk of hospital admissions, repeat admissions, co-morbidity and deaths.'

The interesting paper by McAllister and colleagues in this issue of the $P C R J$ examines the additive effect of socio-economic deprivation on seasonal hospital admissions in COPD patients. ${ }^{2}$ The authors found a greater number of winter admissions for COPD in the most deprived compared to the least deprived quintile of the Scottish population (39 versus 7 extra admissions per 10,000 patient years between summer and winter respectively). Previous studies in England and Wales have shown no difference in excess winter deaths between areas with greater or less deprivation or colder housing. ${ }^{3-6}$ Indeed, excess winter mortality of working men aged between 50-59 years in the lowest social group (class 5) is lower than any other social class possibly because of their increased activity and that they take precautions against the cold during their manual occupations.

The findings by McAllister and colleagues can be explained by their unique approach to the question. They investigated whether the joint effect differs from the sum of the effects caused individually by temperature and deprivation. Thus, they found that patients with COPD are more likely to be admitted to hospital for an exacerbation beyond what one would expect because it is cold outside and they live in a deprived area. The cause of these extra admissions could be due to the synergistic effect of poor housing being more expensive to heat.

The study does have implications, as the demands on community care systems will be greater because more of the COPD patients discharged from hospital will be from a socio-economically deprived background. Targeting help for these patients is more problematic; interventional studies have so far failed to show any reduction in mortality or morbidity due to housing and heating upgrades, though improvements have been seen in quality of life indices. ${ }^{8}$ This may be due to the small sample size of these trials performed in the community for practical reasons. Targeting home improvement schemes just at elderly people is also politically difficult - inevitably those elderly people who live with their families will not be as high a priority.

An important limitation of McAllister et al.'s study was the use of monthly data. There are fewer admissions to hospital over the weekend and the number of weekends in each month will differ. Also, fewer patients are admitted during Christmas and the New Year periods, and this will affect the hospital admission numbers on a monthly basis. ${ }^{9}$ Cold weather also has a delayed effect on people, with peak mortality from respiratory disease occurring 12 days after peak cold. ${ }^{10}$

Though this study showed a disproportionate effect of cold weather on the most deprived, Keatinge ${ }^{11}$ reported that excess winter deaths in the general population were no different from able bodied elderly people, mainly women, living in warden controlled housing where the costs of heating did not depend on how much the resident used. However, inadequate home heating is not the only cause of winter mortality, and outdoor cold exposure is also important. ${ }^{12}$ Wearing suitable protective clothing such as a hat and gloves in cold weather is beneficial but this advice is often neglected by patients. Other reasons are that COPD may be underdiagnosed in patients with socio-economic deprivation and thus this group is more likely to develop more severe exacerbations with a respiratory infection.

McAllister and colleagues report that there were around 30\% more hospitalised COPD exacerbations in the winter than in the summer months. ${ }^{2}$ Large well designed public health interventional studies are now needed to investigate these observations further. It is likely that deprivation and season may also interact together to increase COPD exacerbations of mild to moderate severity. Therefore, 